\title{
The Contribution of other Eminent Scholars to \\ Lijphart's Power-Sharing Theory
}

\author{
Ramin Mafakheri (Corresponding Author) \\ Department of Politics and Government \\ Faculty of Human Ecology, Universiti Putra Malaysia (UPM) \\ 43400, Serdang, Selangor, Malaysia \\ ramin.maf@gmail.com \\ Zaid Bin Ahmad \\ Department of Politics and Government \\ Faculty of Human Ecology, Universiti Putra Malaysia (UPM) \\ 43400, Serdang, Selangor, Malaysia Jayum@upm.edu.my \\ zaid_a@upm.edu.my
}

Accepted: April 05, 2015

Doi:10.5296/ jpag.v5i2.7306 URL: http://dx.doi.org/10.5296/ jpag.v5i2.7306

\begin{abstract}
Power-sharing theory, which is both prescriptive and empirical, is one of the seminal democratic theories in political science in general and comparative politics in particular. In order to gain an in-depth understanding of the theory and rationale for its development, it should be considered that while Lijphart's name is prominently associated with the development of it, there are also several eminent scholars who simultaneously worked on power-sharing democracy and the improvement and development of the theory; From this point of view, the intellectual contribution of these scholars is particularly considered in this article.
\end{abstract}

Keywords: Power-sharing theory, power-sharing democracy, consociationalism, consociational scholars. 


\section{Introduction}

Lijphart's power-sharing theory was shaped primarily as a clarification of political stability in a few smaller segmented European countries in the late 1960s. This theory serves to solve the problem of achieving and maintaining democratic stability in plural societies. The construction and development of Lijphart's theory by and large can be clustered into two phases: first it merely focuses on the relationship between political cleavages and political stability in divided societies in which consociational democracy is the outcome of this stage. The second phase considers more variables; democratic stability and democratic quality in both homogenies and nonhomogeneous societies.

Lijphart's intellectual attempts, initially began with analyzing the sociopolitical cleavages of the Netherlands in his seminal book The Politics of Accommodation (Lijphart 1968); Indeed, consociational democracy grew out of these studies. It was formulated based on two closely related variables; on the one hand socio-political aspects that entail segmental cleavages and on the other hand the political side that considers coalescing elites or the accommodation of the segmental elites which lead to democratic stability.

In the 1960s, Lijphart's theory had comprehensively challenged majoritarianism and presented an appropriate solution to the old problem of divided societies: establishing a democratic political system based on a high degree of quality and political stability. In the words of Crepaz and Steiner (2012, p. 269) consociational or power-sharing democracies, as the outcome of Lijphart's theory, 'stand in contrast to competitive majoritarian democracies, the latter being characterized by a voting mechanism whereby a majority can impose its will on a minority.'

In general, the origins of consociationalism can be traced back to the simultaneous intellectual attempts of a number of consociational scholars in the late 1960s. therefore, while Lijphart's name is prominently associated with the development of power-sharing (consociational) theory, there are several eminent scholars who simultaneously worked on power-sharing democracy - each one with a special interest in a country - mostly in the late 1960s and early 1970s: For instance, Lehmbruch particularly focused on Austria and Swiss democracy, Steiner on Switzerland democratic political system, and Huyse on Belgium democracy.

In other words, in the 1960s and 1970s, consociational/power-sharing democracy was considered by a number of the world's leading political scientists. It principally was as the outcome of the simultaneous independent but overlapping work of Lijphart(1968; Lijphart 1968; Lijphart 1969; Lijphart 1977; Lijphart 1979; Lijphart 1981), Daalder(1971; Daalder 1974), Powell (1970), Steiner (Steiner 1969; Steiner 1969; 1971; Steiner 1974), Lorwin(1971), and McRae(1974). These works should not merely be considered as the institutional and historical studies of some specific countries. In this regard Daalder(1974, p. 606) points out that, 'we are presented with sophisticated monographs that have much to offer, not only to specialists in comparative politics, but also to students of normative and empirical 
democratic theory and of political sociology.'

From what all these works consider, we can find a number of common characteristics: First, while these studies were in contradiction of prevailing normative interpretations, they supported the type of democracy that Lijphart has called the consociational model. Second, all these studies exclusively dealt with the political experience of a number of smaller European countries. While the study of these countries was ignored in the map of comparative politics until before the 1960s, the studies played an influential role on the development of consociationalism. Therefore, third, they are not only a simple case study of a particular country; borrowing from Lijphart(1968a, p. 15), they are 'an extended theoretical argument based on a single case of particular significance to pluralist theory.'Thus, in this article, the eminent consociational scholars' thought and their contribution to the development of power-sharing theory will be discussed.

\section{Conceptual Clarification}

There are two different concepts that are used for introducing Lijphart's theory; consociational and power-sharing. Using both terms is conceptually ambiguous and need to be clarified. The term consociation has such a long pedigree that Barry (1975, p. 478) stated 'indeed I do not believe I have ever seen it used outside the writings of contemporary political scientists.' Barry (p. 478) also points out that, according to the Oxford English Dictionary, consociation can be used as an 'abstract noun for 'the action or fact of associating together; union in fellowship; combination' or to refer to actual associations, unions and combinations'

In the sense of 'an alliance or confederation' it is now said by the OED to be obsolete, but it seems that its main use at any time (and now its sole use) as a concrete noun has been in the context of formal co-operative arrangements among churches and in particular to refer to confederal ties among Presbyterians and (in the USA) Congregationalists (Barry, 1975, p. 478).

In the words of Barry (1975, p. 480)'Consociational democracy' as conceptualized by Lijphart puts together in a package stability, dissensus, segmentation, elite accommodation and some mix of the 'consociational devices'. Related to, Steiner(2013a, p. 269) points out that 'Lijphart and Lehmbruch coined the term consociational democracy to draw attention to some smaller European democracies that were neglected in prior theorizing.' In Lijphart's(2008, p. 6) own words he 'started to use consociationalism not only as an analytical concept but also as a practical recommendation for deeply divided societies.'

The term consociationl in his theory was borrowed from David Apter's 1961 study of Uganda. In Lijphart's (p. 3) own words 'it can actually be traced as far back as Johannes Althusius' writings in the early seventeenth century; Althusius used the Latin consociatio.'Lijphart used the term consociational for the first time in his 1968 and 1969 articles (Munck 2007). Lijphart in his writings after 1969, started to use the term power-sharing for describing one of his non-majoritarian models of democracy; power-sharing democracy. It is worth emphasizing that Lijphart began to use the term power-sharing democracy also as a synonym 
for consociational democracy (Lijphart 2008). The term power-sharing in the theory means the contribution of the representatives of all significant groups to political decision-making, particularly at the executive level(Lijphart 2002). It is worth mentioning that the concept of power-sharing also has often been used as a rough synonym for the term consensus democracy that grew out of Lijphart's attempt to describe and measure consociational democracy more accurately (Lijphart 2008).

Why did Lijphart start to use the term power-sharing instead of consociational? In Lijphart's(2008, p. 6)own words, "the term "consociational" worked well enough in scholarly writing, but I found it to be an obstacle in communicating with policy-makers who found it too esoteric, polysyllabic, and difficult to pronounce. Using "power sharing" instead has greatly facilitated the process of communication beyond the confines of academic political science.'Therefore, it is worth noting that the terms consociational democracy and consensus democracy should be considered within non-majoritarianism; in other words, they are both non-majoritarian, or what even Lijphart(1989) has called 'anti-majoritarian' types of democracy. Of course, each one has its own roots and they were also derived from different circumstances that will largely be discussed in the chapters on the findings.

\section{Development of Lijphart's Theory and Contribution of other Eminent Scholars}

\subsection{Steiner from Amicable Agreement to Deliberative Democracy}

Jurg Steiner, as one of the eminent political scientists, has steadily attempted to contribute to developing power-sharing theory since the 1960s. Steiner's contribution by and large could be considered from three angles; through (1) scrutinizing the social and political structure of Switzerland; (2) criticizing the theory from different perspectives and also his recommendations; (3) developing the theory in the light of opening a new standpoint; deliberation and deliberative democracy.

Steiner's effort to make contribution to developing power-sharing (consociational) theory began with his focus on analyzing social and political structure of Switzerland as a multicultural and multilingual country. This country in Lijphart's(1999) interpretation has been introduced as one of the most stable models of democracies in the world; consensus democracy. In the words of Lijphart (p. 34), the consensus model of democracy seeks 'to share, disperse, and restrain power in a variety of ways.'

Steiner (1969) introduced the political system of Switzerland as one of the few democracies with very little violence and regulation of its political conflicts for a long time. Here, political nonviolence has been considered as an element of democratic stability. In Steiner's view hypotheses about the requisites of democratic stability are valid for the requisites of political nonviolence. Of course, most hypotheses that were presented in the literature of his studies are not only concerned with political nonviolence but also deal with other criteria of democratic stability in Switzerland as a multicultural and multilingual country.

Steiner (1971) in The Principles of Majority and Proportionality illustrates one of the controversial matters in power-sharing theory; applying 'majority principle' and 'proportionality' to the political decision-making process. In fact, each model comparatively 
denotes the regulation of conflict in different ways; while in the majoritarian model majority decisions denote the regulation of conflict, in the proportional model all groups influence a decision proportionally based on their numerical strength. In this regard, five hypotheses were tested based on a comparative study between the political system of Switzerland and other political systems.

In a critical article, The Consociational Theory and Beyond, Steiner (1981) criticized Lijphart's seminal work Democracy in Plural Societies(Lijphart 1977) with regard to four arguments: first, there is no clear operational measure to determine whether a society is plural or not. In other words, it is not clear how to distinguish accurately plural from non-plural societies in general, and cultural diversity and subcultural segmentation in particular. Second, while consociational (power-sharing) theory generally distinguishes two major modes of decision making - the competitive and consociational models of decision making - within countries, Steiner (p. 340) suggests that 'it is more reasonable to take, as the units of analysis, decision making for individual conflicts and not for entire countries.'

Moreover, regarding the significance of the decision-making mode for establishing democratic stability, Steiner, in different works, (e.g. Steiner \&Lehnen, 1974, Steiner, 1987, Steiner \&Dorff, 1980, 1981, and etc.) has investigated various political decision modes with a particular interest in political decision making in segmented societies. In this regard, Steiner (1981) argues that it is time to change the basic research strategy in order to go beyond consociationalism towards a more general theory of political decision making.

Later, in European Democracies Steiner (2013) highlights that decision making as a key theoretical variable has been employed in much cross-national research; in this regard, corporatism and consociationalism are introduced as the two prominent approaches. Here, it is worth noting that in Steiner's (1981) view, understanding the decision-making process in a divided society depends on studying the effects of cultural identities on that process. He emphasizes that consociational decision making in segmented societies is not only more likely to reduce violence but also to contribute to the creation of stability.

From a methodological perspective, in Structure and Process in Consociationalism and Federalism, Steiner and Droff(1985) emphasize that in the studies of consociationalism and federalism the distinction between structure and process should be more carefully considered. They argue that characterizing the institutional structure of a political system as consociational or federal is easy, but in contrast, turning from structure to the decision process is much more difficult. In fact, the structural and process elements need different research methods as well as different level of analysis so that it is not easy to aggregate them in a single measure.

\subsection{ValLorwin; Segmented Pluralism}

Val R. Lorwin (1907-1982) particularly focused on the case study of Belgium. Referring to this country, Lijphart(1981) argues that in comparison with most other divided societies in the contemporary world, Belgium's remarkable point is its cultural communities that coexist peacefully and democratically. Lorwin, in a seminal article, Segmented Pluralism(Lorwin 
1971), of course, more comprehensively considered the characteristics of segmented pluralism and its conditions in not only Belgium, but also in some other countries such as the Netherlands, Switzerland, Luxembourg, and Austria.

Segmented pluralism in Lorwin's studies is 'a degree of vertical subcultural encapsulation and AUTONOMY sufficient to minimize the opportunity for conflict between the subcultures'(Luther, 2001, p. 113). Lorwin classified the extent of segmented pluralism in these countries and argues that segmented pluralism has been noticeable in the social mobilization of these plural societies. In this regard, Lorwin distinguishes three different levels of segmented pluralism: high, medium, and low.

It is worth noting that these three categories were applied by Lorwin(1971) to numerous spheres of activity such as socioeconomic organizations, political affiliations and government, education, and mass media. Nevertheless, he narrowed his investigation to the lines of religious and political cleavages. Therefore, in Lorwin's(1971, p. 142)perspective by and large a political system is called segmented pluralism when 'its cleavages have produced competing networks of schools, communications media, interest groups, leisure time associations, and political parties along segmented lines, of both religious and antireligious nature.'

It also is worth noting that while Lijphart's analysis highlighted both aspects of plural societies - the segmental cleavages of the society and the political cooperation of the fragmented elites - Lorwin's segmented pluralism and his classification only entails the investigation of the social aspect. In other words, in comparison to Lijphart's attempts, Lorwin neglected the political aspect and particularly considered the segmental cleavages of religious and ideological phenomena in plural societies.

\subsection{Bingham Powell; from Austrian Case Study to Generalization}

Powell's intersection with Lijphart's scholarship on power-sharing theory began with the Austrian case study in the 1970s; and later examining the political performance of power-sharing democracies from different perspectives in comparison with the majoritarian version of democracy. In the words of Lijphart(1971) the Austrian experience in the Second Republic was the best example of consociationalism. Lijphart(pp. 13-14) points out that whereas the British type of democracy has had an excellent impact all over the world, 'there is no reason why the Austrian model could not serve as an alternative normative example-and one that is more appropriate to the many fragmented countries than the British model.'

According to one of Lijphart's(1977) contributions to democracy in plural societies, the main social cleavages tend to be shifted into party system cleavages. In this regard, Austrian stability based on party system cleavages was an appropriate example which was explained by him in the light of the consociational type of democracy. Lijphart(p. 62) points out that Austria's stability was basically because of 'the cooperation of the rival elites in a grand coalition, and the two-party system, especially in the earlier years, was a strain on this overarching cooperation rather than a support for it.'

On the other hand, Powell's contribution to the development of power-sharing theory began 
with studying the Austrian political system in order to highlight its stability. Powell (1970), in his seminal work, Social Fragmentation and Political Hostility, focused on the analyses of the political life and the fragmented society of Hallian ${ }^{1}$.In this connection, Daalder(1974, p. 605) points out that 'Powell chooses the narrow focus of a single Austrian city to administer a survey that seeks answers to major theoretical issues.'

This study was based on a 1967 survey of people due which analyzed the relationship between social fragmentation as the independent and political hostility as the dependent variables. According to his empirical analyses, fragmentation leads to governmental ineffectiveness on the one hand and unequal access to the governing elite on the other. Of course, Powell argues that fragmentation should not be considered in completely negative terms. In this connection, Powell (1970, p. 137)points out that there is a noticeable paradox so that 'harmony is both comfortable and stifling; that conflict is both enriching and disruptive.'

Powell's most direct point of intersection with Lijphart's power-sharing theory is displayed in his work Contemporary Democracies (Powell 1982); In this important comparative study Powell tries to tie together different theoretical problems what have long existed in the field of comparative politics. Therefore, the author chose twenty-nine democracies among European and non-European democracies, except Africa. Powell(1982, p. 1)in this work, attempts to answer a central question; 'why does the political process work more successfully in some democracies than in others?'

In this study, democratic performance is illustrated based on three main standards: the electoral participation of citizens, political order, and government stability. Lijphart's theory was discussed in the last chapter of Powell's 1982 work; he seeks to measure and analyze Lijphart's discussion of "consociational" practices as a variableand does some multivariate analysis on adding a measure of consociational practices to Lijphart's equations on deadly violence.

In general, Powell adopts Lijphart's argument that there is a set of unwritten rules constructed by the elite in order to protect a political system against the threat of group divisiveness. Furthermore, Powell agrees that while these types of consociational practices are encouraged through non-majoritarian party systems, representational constitutions and multiparty, consociationalism (the power-sharing theory) goes beyond them, so that it emphasizes coalitions and guarantees a substantial accommodation among all main groups (1971).

Besides, while Powell also does not ignore the successes of the examples of consociational practices such as the Netherlands, Belgium, and Switzerland, etc. he emphasizes two important warnings: first, all the parties' signal willingness to work, based on accommodative bargains is vital to the success of consociational democracy. Moreover, participation by all political parties and mutual vetoes show that any new policies can be blocked by a recalcitrant group. This can happen to the benefit of the followers of the status quo and as a drawback of the have-nots. Second, the leaders' performance based on accommodation is not

\footnotetext{
1. Hallian is a small industrial city in Austria.
} 
enough if they do not have the sustainable support of their followers or if large parts of people are not mobilized at all. Thus, the emergence of a power-sharing political system would be vulnerable to new elites who are going to make new promises (Powell 1982).

Powell, in his 2000 work, Elections as Instruments of Democracy (Powell 2000), has built on a typology and conceptualization rather similar to Lijphart's. But he is trying to explain a rather different dependent variable, the roles of elections in connecting citizens and policymakers.In this empirical study, elections are explored as instruments of democracy. Hence, about 155 elections of the twenty contemporary democracies are considered. In general, Powell examines the differences of political elections between two main models of democracy; on the one hand, the majoritarian model which emphasizes choosing decisively between two parties as the main policymakers and on the other hand the proportional model where political agents are chosen by citizens to represent their attitudes in postelection bargaining and a coalition government.

\subsection{Hans Daalder; the Netherlands'Political System}

Daalder was one of the first influential consociational scholars so that Lijphart(1997) agrees that The Politics of Accommodation and a number of his articles on Dutch politics were heavily inspired by and drew from Daalder's ideas; in Lijphart's own words 'In 1964, I had met Hans Daalder, a professor at the University of Leiden, and he was plotting to get me back to Holland'(Munck, 2007a, p. 265). It also is worth mentioning that Lijphart was in touch with Daalder when he participated as a member of the team working on the Smaller European Democracies project in the Center for Advanced Studies in Berkeley in 1966-67 (Munck 2007). What is worth considering here is that the democratic systems of European smaller countries later became basic patterns for constructing Lijphart's power-sharing theory.

The Netherland was Daalder's first case study; he published some important works as the first step of analyzing the political system - of a fragmented as well as a stable country what later was called consociational democracy. Daalder(1996, p. 7)points out that the Netherlands is one of the rare countries which has been considered persuasively in the field of comparative politics, in his own words, it 'was by my one-time fellow countryman, now an American citizen, ArendLijphart who derived his model of a 'consociational democracy' from it.'

Daalder, in his 1974 work, The Consociational Democracy Theme, from different points of view attempted to introduce the origins of his cosnsociational model of democracy. He argues that this model arises from a recognized proposition in the theory of pluralist; accordingly, if different cleavages cut across one another, the social cleavages would lead to moderation. But if they cumulatively reinforce one another, the social cleavages become loaded with conflict (Daalder 1974).

Dallder's aim, as the editor of Party System in Denmark, Austria, Switzerland, the Netherlands and Belgium(Daalder 1987), was to examine the development of the party systems of five European power-sharing democracies since the Second World War. Furthermore, it is worth pointing that Daalder(1987, p. xii)according to the studies of political 
systems of these power-sharing democracies argues that any of three levels of the political system could be originated by a change in party and party systems: 'in the interaction of parties at the level of government and parliament; in the relation between parties and voters; and in the internal development of parties.'

Daalder's State Formation, Parties and Democracy(Daalder 2011) is a study of European comparative politics that consists of the re-publication of his classical studies with emphasize three main themes: modernization and the various paths toward the formation of the state in Europe; their impact on political parties and party systems; and the rise and merits of power-sharing (consociational) model of democracy. In the last theme that particularly focused on the consociational model of democracy, Daalder considers building consociational nations in two case studies; the Netherlands and Switzerland. Furthermore, he particularly focuses on analyzing the theme of consociational democracy from the perspectives of some important consociational scholars (Daalder 2011).

In brief, Daalder categorized four consociational scholars' seminal works in the 1970s; these studies have been considered to share three significant characteristics: First, they exclusively or at least mostly deal with the political experience of several smaller European countries that are not well-known in comparative politics. Second, they are much more than simple studies of some specific countries. Third, these works present a tough challenge to the current typologies of democratic regimes and offer different conditions for democratic stability. In addition, they are applicable to the version of democracy that Lijphart has called the consociational model (Daalder 1974).

\subsection{Kenneth Douglas McRae; the Case Study of Canada}

McRae, with regard to the basic term "consociational", brings together an outstanding collection of essays. These articles are grouped into two parts: one contains the theoretical perspectives and other applications and illustrations of some European examples such as the Netherlands, Austria, Switzerland, and Belgium, as well as some comments on the Canadian political experience (e.g. Consociationalism and the Canadian Political System by McRae). In brief, this 1974 book is a weighty contribution to the debate on sharing power in theory and practice in general, and the division of power in the constitution of Canada in particular.

McRae's Conflict and Compromise in Multilingual Societies(McRae 1983; McRae 1986; McRae 1997) in three volumes are other important works in the school of consociationalism. In these three volumes the history, social, attitudes, and political structure as well as institutions within some European pluralist countries such as Switzerland, Belgium, and Finland were considered. In these seminal works, an underlying question was posed by McRae (1997, p. i); "by what means can a multilingual country arrive at linguistic peace and justice for different language groups?" Therefore, by and large, the linguistic groups of the countries in question begin with the study of demographic changes in ethno-linguistic populations.

\section{Conclusion}

Referring to what has been discussed in this article, it can be conclude that while 
power-sharing theory is typically connected with Lijphart's name, there have been a number of consociational scholars who have made contribution to the development of the theory in the 1960s and 1970s. In summary, power-sharing theory particularly considers two overlapping aspects in divided societies; the relationship between the fragmented sociopolitical aspect and political stability. The overview of the literature of power-sharing theory has indicated three different approaches. The first approach merely concentrates segmental cleavages or the sociopolitical side of the theory; For instance, according to Lowin's studies, segmented pluralism can effectively reduce the potential of immobility or de-stability of hostile cleavages.

In contrast, the second approach -e.g. the works associated with Lehmbruch, Daalder, and Steiner-have mainly considered the political side of the theory. They argue that the democratic stability of their case studies is because of the traditional method of decision-making and proportionality; what Steiner has called "Amicable Agreement". Of course, Steiner particularly has focused on political culture and argues that it was neglected in Liphart's theory.In this regard, Steiner has tried to develop the theory in the light of opening a new standpoint; deliberation and deliberative democracy. In comparison to the first two approaches, Lijphart, as the pioneer of the third approach concentrates on both sociopolitical and political sides, so that power-sharing theory is the product of this prima facie paradoxical overlapping.

\section{References}

Barry, B. (1975). "Political Accommodation and Consociational Democracy " British Journal of Political Science5(4): 477-505.

Crepaz, M. and J. Steiner (2012). European Democracies. New York, Pearson.

Daalder, H. (1971). "On Building Consociational Nations: The Cases of the Netherlands and Switzerland." International Social Science Journal23(3): 355-370.

Daalder, H. (1974). "The Consociational Democracy Theme." World Politics24(4): 604-621.

Daalder, H., Ed. (1987). Party Systems in Denmark, Austria, Switzerland, The Netherlands and Belgium. London, Frances Pinter.

Daalder, H. (1996). "The Netherlands: Still a Consociational Democracy?" Institut für Höhere Studien (IHS) / Institute for Advanced Studies (33): 1-18.

Daalder, H. (2011). State Formation, Parties and Democracy: Studies in Comparative European Politics. Colchester, ECPR Press.

Lijphart, A. (1968). The Politics of Accommodation: Pluralism and Democracy In The Netherlands. London, California, University of California Press.

Lijphart, A. (1968). "Typologies of Democratic Systems." Comparative Political Studies1(1): 3-44.

Lijphart, A. (1969). "Consociational Democracy." World Politics21(2): 207-225. 
Lijphart, A. (1971). "Cultural Diversity and Theories of Political Integration." Canadian Journal of Political Science 4(1): 1-14.

Lijphart, A. (1977). Democracy in Plural Societies: A Comparative Exploration. New Haven, Yale University Press.

Lijphart, A. (1979). "Consociation and Federation: Conceptual and Empirical Links " Canadian Journal of Political Science 12(3): 499-515.

Lijphart, A. (1981). "Consociational Theory: Problems and Prospects. A Reply." Comparative Politics13(3): 355-360.

Lijphart, A. (1981). Introduction: The Belgian Example of Cultural Coexistence in Comparative Perspective. Conflict and Coexistence in Belgium: The Dynamics of a Culturally Divided Society. A. Lijphart. Berkeley, Institute of International Studies, University of California: 1-12.

Lijphart, A. (1989). "Democratic Political Systems : Types, Cases, Causes, and Consequences." Journal of Theoretical Politics1(1): 33-48.

Lijphart, A. (1997). About Peripheries, Centres and other Autobiographical Reflections. Comparative European Politics: The Story of a Profession. H. Daalder. London and Washington, Pinter: 241-252.

Lijphart, A. (1999). Patterns of Democracy: Government Forms and Performence in Thirty-Six Contries. New Haven and London, Yale University Press.

Lijphart, A. (2002). The Wave of Power-Sharing Democracy. The Architecture of Democracy: Constitutional Design, Conflict Management, and Democracy. A. Reynolds. New York, Oxford University Press Inc.: 37-54.

Lijphart, A. (2008). Thinking about Democracy: Power Sharing and Majority Rule in Theory and Practice. London and New York, Taylor \& Francis Groups.

Lorwin, V. R. (1971). "Segmented Pluralism: Ideological Cleavages and Political Cohesion in the Smaller European Democracies." Comparative Politics 3(2): 141-175.

Luther, K. R. (2001). Consociationalism. Encyclopedia of Democratic Thought. P. B. Clarke and J. Foweraker. London and New York, Routledge: 112-115.

McRae, K. D., Ed. (1974). Consociational Democracy: Political Accommodation in

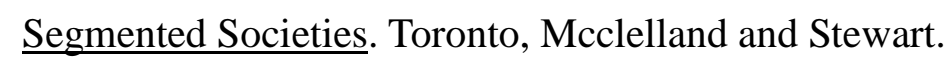

McRae, K. D. (1983). Conflict and Compromise in Multilingual Societies: Switzerland Waterloo, Ontario, Wilfrid Laurier University Press.

McRae, K. D. (1986). Conflict and Compromise in Multilingual Society: Belgium. Waterloo, Ontario, Wilfrid Laurier University Press.

McRae, K. D. (1997). Conflict and Compromise in Multilingual Societies: Finland. Waterloo, Ontario, Wilfrid Laurier University Press. 


\section{MInstitute ${ }_{\text {Mnink }}^{\text {Macrothin }}$}

Journal of Public Administration and Governance ISSN 2161-7104

Munck, G. L. (2007). Arend Lijphart: Political Institutions, Divided Societies, and Consociational Democracy. Passion, Craft, and Method in Comparative Politics. G. L. Munck and R. Snyder. Maryland, The Johns Hopkins University Press: 234-272.

Powell, G. B. (1970). Social Fragmentation and Political Hostility: An Austrian Case Study. Stanford Stanford University Pres.

Powell, G. B. (1982). Contemporary Democracies: Participation, Stability and Violence Cambridge Harvard University Press.

Powell, G. B. (2000). Elections as Instruments of Democracy: Majoritarian and Proportional Visions. New Havan, Yale University Press.

Steiner, J. (1969). "Conflict Resolution and Democratic Stability in Subculturally Segmented Political Systems." Res Publica11: 775-798.

Steiner, J. (1969). "Nonviolent Conflict Resolution in Democratic Systems: Switzerland " Journal of Conflict Resolution13(3): 295-304.

Steiner, J. (1971). "The Principles of Majority and Proportionality " British Journal of Political Science1(1): 63-70.

Steiner, J. (1974). Amicable Agreement versus Majority Rule: Conflict Resolution in Switzerland. University of North Carolina Press, Chapel Hill.

Steiner, J. (1981). "The Consociational Theory and Beyond." Comparative Politics13(3): 339-354.

Steiner, J. (1981). "Research Strategies beyond Consociational Theory." The Journal of Politics43(4): 1241-1250.

Steiner, J. (2013). European Democracies. New York, Pearson.

Steiner, J. and R. H. Droff (1985). "Structure and Process in Consociationalism and Federalism." The Journal of Federalism15(2): 49-55. 